http://www.jfas.info

\title{
SERVICE QUALITY \& MARKETING: A PRACTICAL RELATION
}

\author{
S. H. Hataminasab ${ }^{1, *}$, E. Oliya ${ }^{2}$, Z. Torabi ${ }^{3}$, F. S. Roghani ${ }^{3}$ \\ 1, 2, Department of Management, Yazd Branch, Islamic Azad University, Yazd, Iran \\ ${ }^{3}$ Department of Management, Abadeh Branch, Islamic Azad University, Abadeh, Iran
}

Published online: 16 July 2016

\begin{abstract}
In this paper we aim to study the application of Six Sigma methodology to enhance online brand equity. In this regard, we will review different online brand equity models, brand equity failure modes and ways that online marketers can estimate current and desired sigma level of business branding performance. Research methodology applies on of main Six Sigma models, known as DMAIC (Define, Measure, Analyze, Improve, and Control). In this frame work, we benefit from main tools in each mentioned phase above to reach associated improvement actions to show how business managers can enhance corporate online brand equity by using Six Sigma methodology. In addition the paper can be considered as first researches that investigates the application of Six Sigma technique in the field of online brand equity.
\end{abstract}

Keywords: Six Sigma, online brand equity, DMAIC

Author Correspondence, e-mail: Hataminasab@iauyazd.ac.ir

doi: http://dx.doi.org/10.4314/jfas.v8i2s.36

\section{INTRODUCTION}

Marketing scholars has paid special attention to customer related issues. In a narrower view, branding and its equity for customers is an imperative concept that received much reflection in both modern marketing literature and research interest (Brymer, 2004: Aaker, 1991). 
Even though many works carried to explore brand equity, yet relatively little research focused on improving of brand equity in today's online business environment. In another words, despite a great amount of research on how more money is made by stronger brand equity, little attention is paid to study the way brand equity is created, measured and improved in an online environment.

Second half of our research is based on Six Sigma methodology; a systematic quality improvement program which was originally used to improve products' quality in manufactories.

This paper tries to address this mentioned study gap in the marketing literature, by studying an organized dataset gathered from responses of available 1,000 users of an online book selling web site in order to prioritize importance of 4 components of e-shop's online brand equity.

The second part involves a brief review of the relevant literature and the framework of research. Research design and methodology description of the dataset is then presented in Section Three. Section four summaries the empirical findings with a discussion on the implications concluding the paper in the last phase

\section{Literature review}

The literature review is divided into two main parts. Part one discusses branding and (online) brand equity and the second evaluates application of Six Sigma methodology in non-manufacturing processes.

\section{Branding}

Brand is defined by many marketing masters; Kotler believes that "brand encompasses the name, logo, image, and perceptions that identify a product, service, or provider in the minds of customers. The brand acts in advertising, packaging, and other marketing communications, and becomes a focus of the relationships between a company and its customers" (Kotler et al. 2010).Brand definitions are quite unlike and have been advanced from the consumer's point of view, the company's perception, or in terms of the purpose they serve. A definition of 
brand recommended by Kapferer (2004) states that "Brands are a direct consequence of the strategy of market segmentation and product differentiation".

Even though customers in the past considered brands as a segment of a product in the form of a name, term or symbol (Urde, 1999), today brands are known as a set of promises and expectations defined by market segments (Davis, Buchanan, \& Brodie, 2000). A set of promises covers bundle of attributes that consumers buy and from which they get satisfaction. From another view, brand characteristics are real or deceptive, rational or emotional, tangible or even invisible (Abels, White, \& Hahn, 1999). Webster (2000) believes that a general consumer does not have a relationship with a product or a service but with a brand and product attributes.

In addition, customers' opinions may also affect the way a brand relates to its attributes in a subjective method (Wood, 2000) which are called key determinant of long term business and relationships with consumer. Indeed, these market perceptions of the brand are the basis of the decision-making process for consumers (Bowker, 2003).

Marketers believe that once a brand continuously presents high standards of quality and integrity, it would remain strong and valuable for customers. This is why brand equals the sum of all the mental relations people have around in their minds toward specific product (Brown, 1992) or what customers think in their minds about a specific brand (Abels, White, \& Hahn, 1999). Successful global brands did positively positioned themselves in the minds of customers; it's why people's perceptions from a specific brand name ("Coca Cola: such a joy") seems to be the same or with not special differences. (Aaker, 1991).

\section{Brand Equity}

The brand describes the company's responsibilities and commitments by launching a specific product and its quality or other dimensions of values for its consumers. In addition, brand with no doubt have direct relation on customers' decision making process at points of purchase. Brand equity and product values also defend the customers' behavior to buy products with a price higher than other competitive products in the market (Mercedes Benz). In addition, this competitive advantage simplifies access to the new markets for companies. 
This feature of a brand is defined as brand equity (Farris et al., 2006) which its construct also refers to "the added value a brand name gives to a product or service" (Rios \& Riquelme, 2008).

It is also known as "a set of brand assets and liabilities linked to a brand, its name and symbol that add to or subtract from the value provided by product or service to a firm and to that firm's customers (Cheng, Wu, \&Yen, 2011). Farquhar (1989) also defined brand equity as "the added value to the firm, the trade, or the consumer with which a given brand endows a product".

The importance of brand equity has been explored in different marketing studies, as mentioned in Table 1 below. The hidden fact in the definitions is the growing importance of customers' role in brand equity definitions.

Table 1. Definitions of Brand Equity (Aghaie, Vahedi, Asadollahi, \& Safari-Kahreh, 2014)

\begin{tabular}{|c|c|}
\hline Researchers & Definitions \\
\hline Farquhar (1992) & The added value that a specified brand dedicates to product \\
\hline Aaker (1991) & $\begin{array}{l}\text { A set of assets and liabilities linked to a brand, its name and symbol } \\
\text { that adds to or subtracts from the value provided by a product or } \\
\text { service to a firm and/or to that firms customers. }\end{array}$ \\
\hline Keller (1993) & Marketing effects that exclusively can be attributed to brand \\
\hline $\begin{array}{l}\text { Kamakura } \\
\text { and Russell (1993) }\end{array}$ & $\begin{array}{l}\text { The excessive benefit related to brand that could not be achieved } \\
\qquad \text { with practical functions }\end{array}$ \\
\hline $\begin{array}{c}\text { Yoo and } \\
\text { Donthu (2001) }\end{array}$ & $\begin{array}{l}\text { Various responses of consumer to brand compared with fake goods } \\
\text { when both of them have the same marketing motivator and traits }\end{array}$ \\
\hline Edrem et al. (2006) & $\begin{array}{l}\text { A concept that refer to this idea :the } \\
\text { value of products for customers increases in a condition that firms, } \\
\text { through the time passage, are connected to a collection of unique } \\
\text { elements that form the essence of the brand }\end{array}$ \\
\hline
\end{tabular}


Firms with more added-value demonstrate higher performance and marketing achievements in the market (Myers, 2003). This concept today is known to relate to consumers' experiences, feelings and their perceptions from a specific brand. This term is known as "consumer based brand equity" and it is the 'added value' endowed to a product in the thoughts, words and actions of consumers (Leone, Rao, Keller, Lui, Mcalister, \& Srivastava, 2006).

Customers also asses each brand equity based on their knowledge about that brand. It is why Keller (2003) defines it as "the differential effect that brand knowledge has on consumer response to the marketing efforts of that brand" (Taylor, Hunter, \& Linderberg, 2007). Other scholars also argue that customers' purchasing behavior is influenced by brand image constituted in their minds Ambler (1992).

Some researchers argue that conceptualization of brand equity is based on "social image, value, performance, credibility and attachment" (Lassar, Mittal, \& Sharma, 1995). In this regard, brand equity is categorized into four aspects of brand loyalty, brand awareness, brand associations and perceived quality (Aaker \& Joachimsthaler, 2000):

Brand association is anything related to a specific brand in the mind of customers. At this level, brand association is determined into 11 types of "product attributes intangibles, customer benefits, relative price, use/application, user/customer, celebrity/person, life a style/ personality, product class, competitors and country/geographic area" (Aaker, 1991). Other classifications name attribute, benefits and attitudes as the main divisions of brand associations and consider brand association as "a core asset for building strong brand equity" (Cheng, Wu, \&Yen, 2011).

Brand awareness is the customer ability to identify and remember a particular brand as a member of a certain product category and higher awareness means that the brand gets more consideration in customers' decisions at the points of purchase.

Brand loyalty is the market's interest and positive feelings toward goods or services which sometimes is understood as "the attachment that customer has to brand" (Aaker, 1991).

As the forth factor, customers define perceived quality as the degree of a product or service excellence in the comparison to the other competing rivals in market (Aghaie, Vahedi, Asadollahi, \& Safari-Kahreh, 2014). 
Brand equity emerges from two sources of brand awareness and brand image. Marketing campaigns try to shape such associations in consumer mind. Once brand equity measurement becomes an important concern for marketing directors, they may prefer to benefit from those customer based models such as one characterized by Keller (2003). As illustrated in Figure 1, in this Customer-Based Brand Equity (CBBE) model, brand equity is measured by application of seven clear measures of salience, imagery, performance, judgments, feelings and resonance (Rios \& Riquelme, 2008). Predictability and validity are two main features of such performance measurement models that encourage managers and marketing researchers to use them in their decisions and studies (Buil, Chernatony, \& Martinez, 2008).
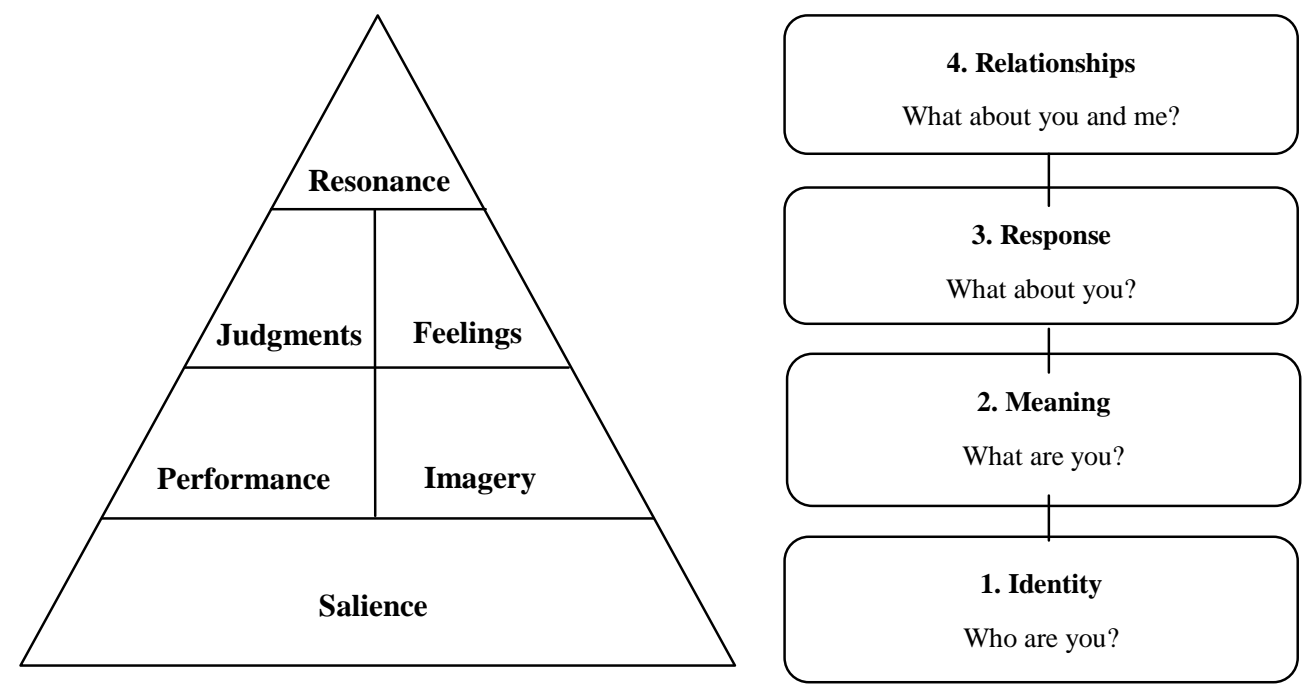

Fig.1. Customer-Based Brand Equity Model (Keller, 2003)

\section{Online Brand Equity}

Today's rapid growth of information technology has led to introduction of series of online businesses which justifies the expansion of marketing perceptions to e-services.

In spite of the development of online businesses, there are limited, specific empirical studies that have established a measure of brand equity for online companies. Reasons for this kind of lack of knowledge are considerations to similarity of brand management in online and offline environment (Rubinstein \& Griffith, 2001) and the role of exceed amount of detailed and latest product information that internet provides for customers that makes them confident enough in their purchasing decisions (Chen, 2001). Technology changes have opened new 
windows to the both internet (mobile access and applications) and the way marketing is influenced by customers' behaviors and experiences in an online world (social media marketing). In this regard some practical findings suggest creating an individual value proposition in the shape of digital brands that can satisfy consumers' needs and expectations (Dayal, Landesberg, \& Zeisser, 2000). Others believe that a company can increase its brand recognition by developing web site design, content, navigation, graphic design and functionality and all factors which make it more user-friendly for online page visitors (Johnson \& Griffith, 2002).

Accordingly, online brand equity like other modern topics in marketing, became a research interest for academics; some of them defined new concepts and models for this challenge, while others customized traditional theories to suite the conditions of new work environment. This effort has led to grow measurement models into online characteristics of brand equity. The Online Retail Service (ORS) brand equity model is one of these representations that is based on five sources of emotional connection, online experience, responsive service nature, trust and fulfillment (Christodoulides, Chernatoni, Furrer, Shiu, \& Abimbola, 2006).

The ORS brand equity model is defined as a "relational type of intangible asset that is co-created through the interaction between consumers and three-tail brand". It is important to note that this is the "first attempt to conceptualize brand equity within the relationship paradigm" (Rios \& Riquelme, 2008). Of course some criticizers believe that 1) this model brand equity is defined in a new way and 2) it does not consider awareness as a part of brand equity (Rios \& Riquelme, 2008). They base their criticism on the fact that ORS hold opposing views with long-established explanations that consider brand equity as "an outcome that accrues to a branded product compared with those that would accrue to an unbranded alternative" (Keller, 2003).

\section{Online brand equity models}

As discussed above, more brand equity brings more competitive advantage for a single company in competitive market atmosphere. Kim et al. (1998) suggest that by planning successful marketing programs, each corporation plays two specific roles regarding its brand equity over the time: establishment and improvement. In B2C businesses, with no doubt, 
managers seek to enhance their brand equity, as way to do well in a market that is different from habitual business environment. This concern, gave enough confidence marketing scholars to design a framework for creating brand equity in $\mathrm{B} 2 \mathrm{C}$ businesses.

Since then, group of marketing researchers like Aaker (1991) and Farquhar (1989) discussed how to model brand equity in their investigations. As discussed in advertising studies, Keller's consumer-based brand equity model (1993) mentions that brand equity exists in "in the mind of the consumer". He considers customers; awareness and knowledge of the product as foundations of brand equity. In customers' purchase decision making process, stronger brand (distinctive brand associations) increases product opportunity to be considered in the customer's consideration set. In online B2C businesses, marketers reach upper degrees of customer awareness and knowledge by applying certain techniques that mentioned in Figure 2 below. Online visitors may increase their online brand awareness by using search engines or watching online advertisings. On the other hand, website (web usability and design) and trust (strategic alliance with reputed firms) are two main sources of customer knowledge when we talk about online brand equity.

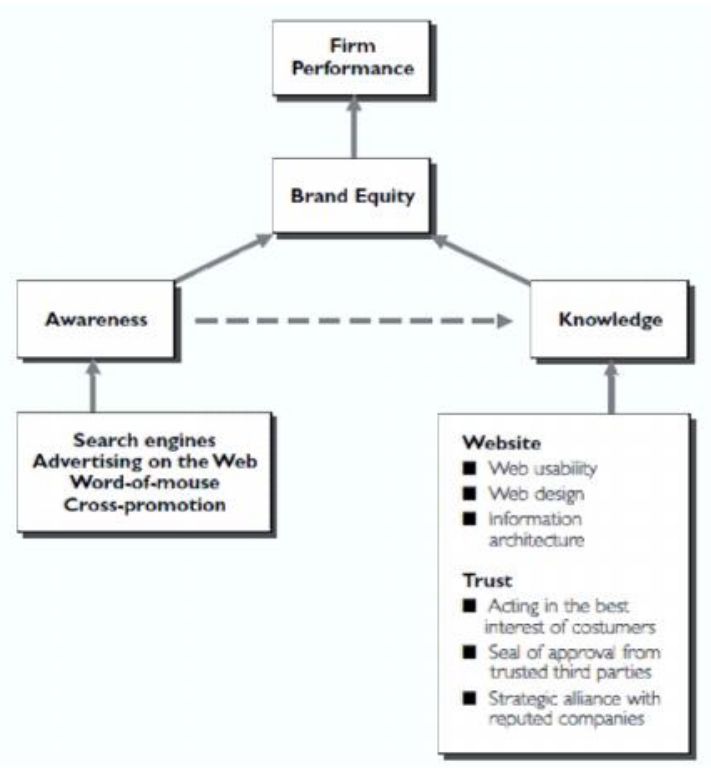

Fig.2. A Framework of Building Brand Equity Online for B2C Businesses (Kim, Sharma, \& Setzekorn, 2002) 
It is worth mentioning that in formulation of online marketing strategies, rational or emotional brand associations and evaluations should be among top priorities for marketing executives, as marketing researchers explored them in their studies.

In this paper, we based our measuring phase of online brand equity in our case study on relative model introduced by Rios. The model covers 4 main elements; named awareness, value and trust associations and loyalty, that make up online brand equity: 1)Awareness: As discussed in the psychological studies of advertising, brand recognition and recall refers to a mental procedure in the minds of customers when they are about to purchase a product, in an online or offline shopping mood. For online businesses, it is vital to dominate their name in the minds of customers. Higher brand knowledge increases the opportunity of re-purchasing from one particular online store and switches a single online visitor into a loyal customer. This becomes crucial when there are many competing online businesses in the market and each market player does it best to distinguish its marketing mix from those of others. 2) Value: Though some researchers haven't included value associations in their brand equity studies, but Rios (2007) instead based her model on the key role of value in brand equity literature. In this view, at point of purchase, consumers consider not only the supposed quality, but the amount of value brought by each specific brand or product (Netemeyer et al., 2004). Higher values don't essentially mean lower prices in product or service. In addition to monetary issues, information (users' web forums), experience (online shopping experience) and support (refund procedures) affect the perceived value for online shoppers today. 3) Trust is another concern for both customers (especially when they do online shopping) and managers (when they develop their web site). Gorriz (2003) believes that shoppers trust in an online environment may suffer from seller's policies in privacy, financial honesty and reputation in the market. 4) Loyalty:

Assael (1992) defines loyalty as a "favorable attitude toward a brand resulting in consistent purchase of the brand over time". Customers' word of mouth marketing and pledge to purchase even at a higher price from a particular merchant (online and offline) relate to the customers' loyalty. 


\section{Six Sigma}

Many scholars discussed Six Sigma; its history (Jernelid \& Roan, 2009; Manual, 2006; Raisinghani et al., 2005), meaning (Kumi \& Morrow, 2006), challenges (Jenicke et al., 2008), tools (Staudter, et al., 2009) and applications (Delgado et al., 2010).

In 1980s, Motorola for the first time used Six Sigma methodology in response todecrease in market share and productivity and an increase in production costs. The company's main challenge in that time was production of 2,600 defected parts and rough competition with Japanese competitors (Raisinghani et al., 2005). The term "Six Sigma" statistically states standard division of one series of datafrom mean which in a normal distribution puts 99.73 percent of data in the range of $3 \sigma$ from the mean. This ideal sigma level equals incidence of 3.4 defects per million opportunities in any quantifiable process. From the company's point of view, Six Sigma could be defined as a process that allows management to noticeably emphasis on continuous improvements in daily business activities that leads toincreased customer satisfaction (Aboelmaged, 2010). Defect can be described as anerror orfault in a process which results in a low level of customer satisfaction. The customer isimportant as it is they who define quality, and any defects in quality can lead to lost customers (Kumi \& Morrow, 2006).

The focus of "Six Sigma" is not on counting the defects in processes, but the numberof opportunities within a process that could result in defects (Antony, 2006) and toenhance customer satisfaction and reduce cost by using facts and statistical analysis (Jernelid \& Roan, 2009).

Six Sigmaincludes four key elements or dimensions in order to comprehend this vision (Staudter et al., 2009): first of all the repeated cycle to optimize processes; called the DMAIC (Define, Measure, Analyze, Improve, and Control). The second one is the practical model for developing processes and products, called the DMADV (Define, Measure, Analyze, Design, and Verify) that also is known as DFSS or Design for Six Sigma. The third one is lean tools applied in the two above-mentioned methods and the last one is process Management for ensuring sustainability. 
Increased importance of service industry in global business environment has made many companies to employ customer related quality improvement programs to offer services meeting as much as customer needs and expectations.

In addition to financial benefits, application of Six Sigma in many service organizations has improved the accurateness of resources allocation; customer and employee satisfaction, process cycle time and service delivery besides cross-functional teamwork across the entire organization (Aboelmaged, 2010).

While Six Sigma has been very popular in manufacturing and services for years, sales and marketing leaders have only recently started to use it. This deferred appreciation is the result of four main factors (Pestorius, 2007): (1) Facilities: Not like manufacturing with calculable processes that enablesexecutives to have control over input variables, marketing improvementprograms are entrenched in the psyche and culture.

Professionalqualifications: most of Six Sigma experts hailed from manufacturing sector and is often less familiar with transactional processes likemarketing. This lack of understanding is noteworthy, because to successfullyapply Six Sigma one must be familiar with both the Six Sigma tools and thesituation in which they are being applied. (3) Consumer purchasing patterns: relying too much on periodic increased in salesrevenues, caused group of marketing executives to disregard any marketingimprovements programs. (4) Current sales culture: applying Six Sigma requires changing both processes andattitudes. When everything seems to be working well, it is difficult to persuade peoplethat change is required.

Six Sigma tools help reaching higher levels of quality in a statically way. Almost all researches that relate to the concept of Six Sigma use these tools. Table 1 shows which tools are frequently used in each of DMAIC's phases (Oliya, et al., 2012). 
Table 2. Most Frequent Six Sigma Tools (Rath \& Strong, 2006)

\begin{tabular}{|l|l|l|l|l|l|}
\hline \multicolumn{1}{|c|}{ Tool } & D & M & A & I & C \\
\hline Business case & $\bullet$ & & & & \\
\hline Project Charter & $\bullet$ & & & & \\
\hline Cause and Effect Diagrams & & & $\bullet$ & & \\
\hline FMEA (Failure Mode and Effect Analysis) & & $\bullet$ & & $\bullet$ & $\bullet$ \\
\hline Consensus & & & & $\bullet$ & \\
\hline CTQ (Critical to Quality) Tree & $\bullet$ & & & & \\
\hline Prioritization Matrix & & $\bullet$ & & $\bullet$ & \\
\hline Scatter Plots & & & $\bullet$ & & \\
\hline Stakeholder Analysis & $\bullet$ & & & $\bullet$ & \\
\hline Times Series Plot (Run Charts) & & $\bullet$ & & & \\
\hline Process Sigma & & $\bullet$ & & $\bullet$ & \\
\hline Quality Control Process Chart & & & & & $\bullet$ \\
\hline SIPOC & $\bullet$ & & & & \\
\hline VOC (Voice of Customer) & & & $\bullet$ & $\bullet$ & \\
\hline Brainstorming & & & & & \\
\hline
\end{tabular}

\section{METHODS}

The main feature of the DMAIC, as most known model in Six Sigma, is its focus on improving current procedure, while design for Six Sigma tries to redesign new process. Other Six Sigma tactics include define, measure, analyze, design and verify (DMADV), define, measure, analyze, design, optimize and verify (DMADOV), identify, characterize, optimize and verify (ICOV), identify, design, optimize and validate (IDOV), define, customer concept, design and implement (DCCDI) and define, measure, explore, develop and implement (DMEDI) (Chakrabarty \& Chuan, 2007). DMAIC (with phases below) provides wide-ranging view of improvement program from definition of current status and process details up to taking the control actions needed to maintain the achievements: Define: to define the customer requirements and expectations for product or services. Measure: to develop a data 
collection plan for the current process. Analyze: to find out the gap between the current and expected performance. Improve: the set of solutions on the basis of root causes identified in analyze phase. Control: to preserve of the improved process. (Zhang \& Khan, 2008)

Information needed by DMAIC phases gathered from users of Iketab online bookstore and in each phase, associated Six Sigma tools used to recommend proper actions to enhance brand equity.

Define phase identifies the store's challenges in branding and increasing its equity. For measurement, the sigma level regarding brand equity is based on Rios's brand equity index (Rios, 2007). The FMEA in analysis phase detects failures during brand development and offers appropriate measures (Staudter et al. 2009). Prioritization matrix arranges improvement actions which are then followed by control actions in the last phase.

\section{RESULTS AND DISCUSSION}

In this research tools are used in each DMAIC phase based on their relation to both the concept of brand equity and the amount of available marketing data.

\section{Define Phase}

In order to enhance brand equity using DMAIC, first problems should be clarified by tools in define phase. In this phase challenges in online brand equity are characterized. Among series of tools mostly used in this phase, project charter and multigenerational plan are used in this phase.

Project Charter: Project charter reviews the significance of enhancement project for organization. Project members discuss issues that relates to the project which should be considered within next phases. Project scope reflects obviously which factors are in (related) or out (not related) of the scope of the project. Seventeen project team members participated in four brain storming meetings to set the project's goals, benefits and capacities, as explained below: 
Table 3. Project Charter

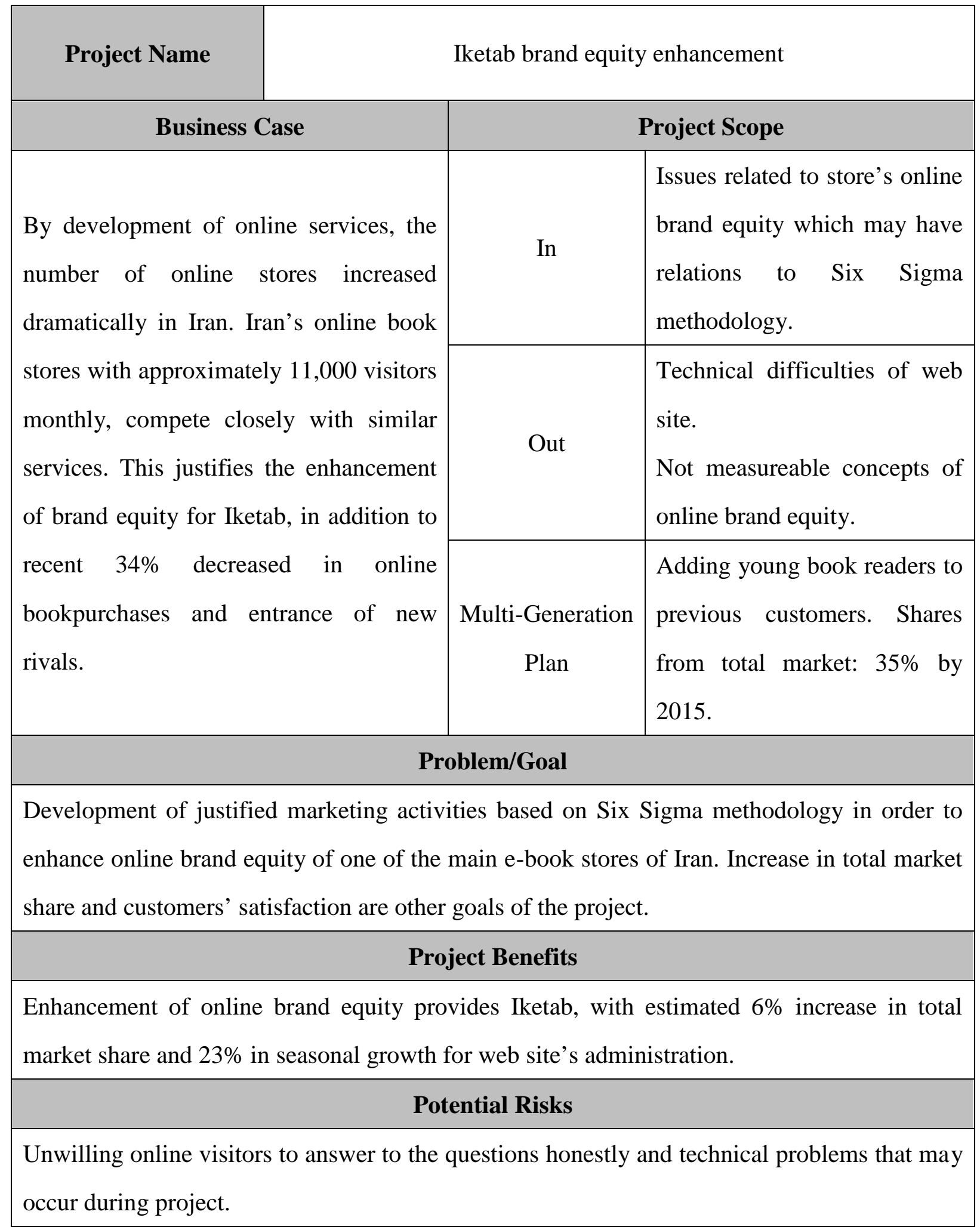


Multigenerational product/process planning (MGPP): MGPP is a procedure that helps team members create, upgrade, leverage, and maintain a product (process) in a way that can reduce production (service) costs and increase market share. Marketing and technical members worked together to prepare MGPP by analyzing (new) generations and technologies that relates to store's online brand equity.

Table 4. Project MGPP

\begin{tabular}{|c|c|c|c|}
\hline & Generation 1 & Generation 2 & Generation 3 \\
\hline Vision/ Goal & $\begin{array}{c}\text { Provision of online } \\
\text { books for educated } \\
\text { customers including } \\
\text { academics and students. } \\
\text { Shares from total } \\
\text { market: } 25 \% \text {. }\end{array}$ & $\begin{array}{l}\text { Adding children and } \\
\text { young book readers to } \\
\text { previous customers. } \\
\text { Shares from total } \\
\text { market: } 35 \%\end{array}$ & $\begin{array}{l}\text { To supply variety of } \\
\text { related online services to } \\
\text { all that have access to } \\
\text { the internet. Shares from } \\
\text { total market: } 50 \% \text {. }\end{array}$ \\
\hline $\begin{array}{c}\text { System } \\
\text { Generation }\end{array}$ & $\begin{array}{l}\text { Based on needs of local } \\
\text { customers to sell } \\
\text { academic books. }\end{array}$ & $\begin{array}{l}\text { Defining more book } \\
\text { categories which are } \\
\text { delivered to buyers' } \\
\text { postal addresses. }\end{array}$ & $\begin{array}{l}\text { An international store } \\
\text { for Persian books. }\end{array}$ \\
\hline $\begin{array}{c}\text { Platforms } \\
\text { and } \\
\text { Technologies }\end{array}$ & $\begin{array}{l}\text { Application of html } \\
\text { programming language } \\
\text { to provide services to } \\
\text { visitors. }\end{array}$ & $\begin{array}{l}\text { Reliable and attractive } \\
\text { web site interface by } \\
\text { using Java. }\end{array}$ & $\begin{array}{l}\text { Reliable, customizable, } \\
\text { Secure online store for } \\
\text { all customers. }\end{array}$ \\
\hline
\end{tabular}

\section{Measure Phase}

In order to measure current online brand equity, we reviewed different brand equity metrics. Inherent characteristics of brand equity make it hard to quantify, especially in an online industry. As Farris explains, even though many specialists (ex. Brand Equity Ten by Aaker, Brand Asset Valuator by Young \& Rubicam and Brand Equity Index by Moran) have 
developed different tools to analyze brand equity, but yet there's no universally accepted way to measure it (Farris et al., 2006).

In this research, we found that in Iketab, online brand equity model best matches to one introduced by Rios in 2007; as mentioned above. One reason to benefit from Rios model is limited number of researches about online brand equity. Besides, unlike Rios, other researchers have not provided online brand equity models with comprehensive views to many factors that influence web sites.

To measure current sigma level, from March 1 to 28, 2014, 1,000 online customers were questioned online that how they think the store's brand equity matches four aspects (Awareness, Association value, Association trust, and Loyalty). This final sample comprised of 1,000 adult respondents, all of whom indicated, as per initial screening, that they had purchased at least one book from website. Over the entire sample, 49.4\% $(n=494)$ indicated that they were male, $43.1 \%(n=431)$ that they were female. (75 individuals failed to answer this question.) The majority of respondents were between the ages of 10 and 30 (73.2\%). This statistic is comparable with the typically youthful profile of online consumers; therefore implicitly positioning this study as primarily analyzing young adults. The majority of respondents $(77 \%)$ made purchases either weekly $(7.8 \%)$, monthly $(35.4 \%)$ or once a year $(55.5 \%)$.

Table 5. Demographics of Survey Respondents

\begin{tabular}{|c|c|c|c|c|c|c|c|}
\hline \multicolumn{3}{|c|}{ Gender } & \multicolumn{7}{c|}{ Age } \\
\hline M & F & NA & $10-20$ & $20-30$ & $30-40$ & $40-50$ & Above 50 \\
\hline 494 & 431 & 75 & 54 & 678 & 112 & 199 & 11 \\
\hline \multicolumn{7}{|c|}{ Purchase frequency } \\
\hline Daily & Weekly & Monthly & \multicolumn{3}{|c|}{ Yearly } \\
\hline 13 & 78 & 354 & \multicolumn{3}{|c|}{555} \\
\hline
\end{tabular}

All question-items were assessed using a 10-point Likert scale where one denoted "very poor" and ten "excellent". Each user rated each component (equally weighted 0.25) from 0 to 10 . To 
reach Sigma level, all marks below 5 were defined as a defect for brand equity. In total, 323 persons said that brand equity needs an urgent improvement plan. In our projectthe initial sigma level was 1.96 .

Table 6. Sigma Level Calculation

\begin{tabular}{|l|c|c|c|}
\hline \multicolumn{1}{|c|}{ Component } & Weight & Customers' rating below 5(defect) & Weighted score \\
\hline Awareness & 0.25 & 341 & 85 \\
\hline Association value & 0.25 & 473 & 118 \\
\hline Association trust & 0.25 & 118 & 29 \\
\hline Loyalty & 0.25 & 360 & 90 \\
\hline Total & 1.00 & 1292 & 323 \\
\hline \multicolumn{4}{|c|}{ Yield $(\%)=($ Non defects/Total opportunities) $* 100=67.7$} \\
\hline \multicolumn{4}{|c|}{ Sigma level = Z (yield)+ $1.5=0.46+1.5=1.96$} \\
\hline
\end{tabular}

\section{Analyze Phase}

This phase identifies roots and causes of problem and uses failure modes and effects analysis. FMEA is one of the most used techniques in project risk analysis to identify possible modes of failure and to forecast their effects and relevance as a result (Segismundo \& Cauchick Miguel, 2008). Several brainstorming meetings held to discuss possible causes of decrease of online brand equity failures. For each failure mode one risk priority number (RPN) is calculated by multiplying severity, frequency and detection rate.

Failure mode and effect analysis (FMEA) is one of the first systematic methods for failure analysis. FMEA studies (negative) effects, main causes and control actions for each situation and in the last step, produces Risk Priority Number (RPN) that means which failure mode has the highest risk for project. As the second tool in this phase, research benefits from cause and effect or Ishikawa diagram that categorizes factors influencing the failure mode with highest RPN happens.

FMEA: In the case of brand equity and based on results of brain storming meeting with store's marketing team members and business advisors, we found that Iketab faces 4 main 
failures. As explained in table below, challenges in customer oriented marketing programs has highest RPN (Risk Priority Number) that is caused by factors including undelivered feedbacks from web site to customers with effects on recurring customer purchases and emotional relations with online book store.

Table 7. Failure Mode and Effect Analysis (FMEA)

\begin{tabular}{|c|c|c|c|c|c|c|c|}
\hline $\begin{array}{c}\text { Failure } \\
\text { mode }\end{array}$ & $\begin{array}{c}\text { Causes of } \\
\text { Failure }\end{array}$ & Effects & 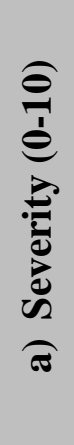 & 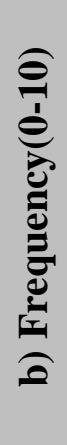 & $\begin{array}{l}\text { Current } \\
\text { controls }\end{array}$ & 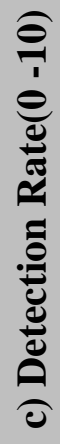 & 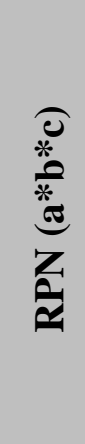 \\
\hline $\begin{array}{l}\text { Not having } \\
\text { outstanding } \\
\text { competitive } \\
\text { advantage } \\
\text { over rivals }\end{array}$ & $\begin{array}{c}\text { Similarity in } \\
\text { services offered } \\
\text { by Iketab and } \\
\text { other market } \\
\text { rivals }\end{array}$ & $\begin{array}{c}\text { Decreased } \\
\text { number of } \\
\text { potential \& } \\
\text { current } \\
\text { customers of } \\
\text { Iketab }\end{array}$ & 6 & 8 & $\begin{array}{l}\text { Creating lasting } \\
\text { competitive } \\
\text { advantage by } \\
\text { e-strategies } \\
\text { plans and } \\
\text { introduction of } \\
\text { these planes in } \\
\text { the web site for } \\
\text { online visitors }\end{array}$ & 3 & 144 \\
\hline $\begin{array}{l}\text { Lacking } \\
\text { aftersales } \\
\text { customer } \\
\text { relations }\end{array}$ & $\begin{array}{l}\text { Inefficient } \\
\text { customers' } \\
\text { complaint } \\
\text { management } \\
\text { Cognitive } \\
\text { dissonance }\end{array}$ & $\begin{array}{l}\text { Unhandled } \\
\text { customers' } \\
\text { complaints } \\
\text { Decreased } \\
\text { feedbacks } \\
\text { from } \\
\text { customers }\end{array}$ & 7 & 5 & $\begin{array}{l}\text { Launching } \\
\text { e-CRM } \\
\text { programs }\end{array}$ & 4 & 140 \\
\hline
\end{tabular}




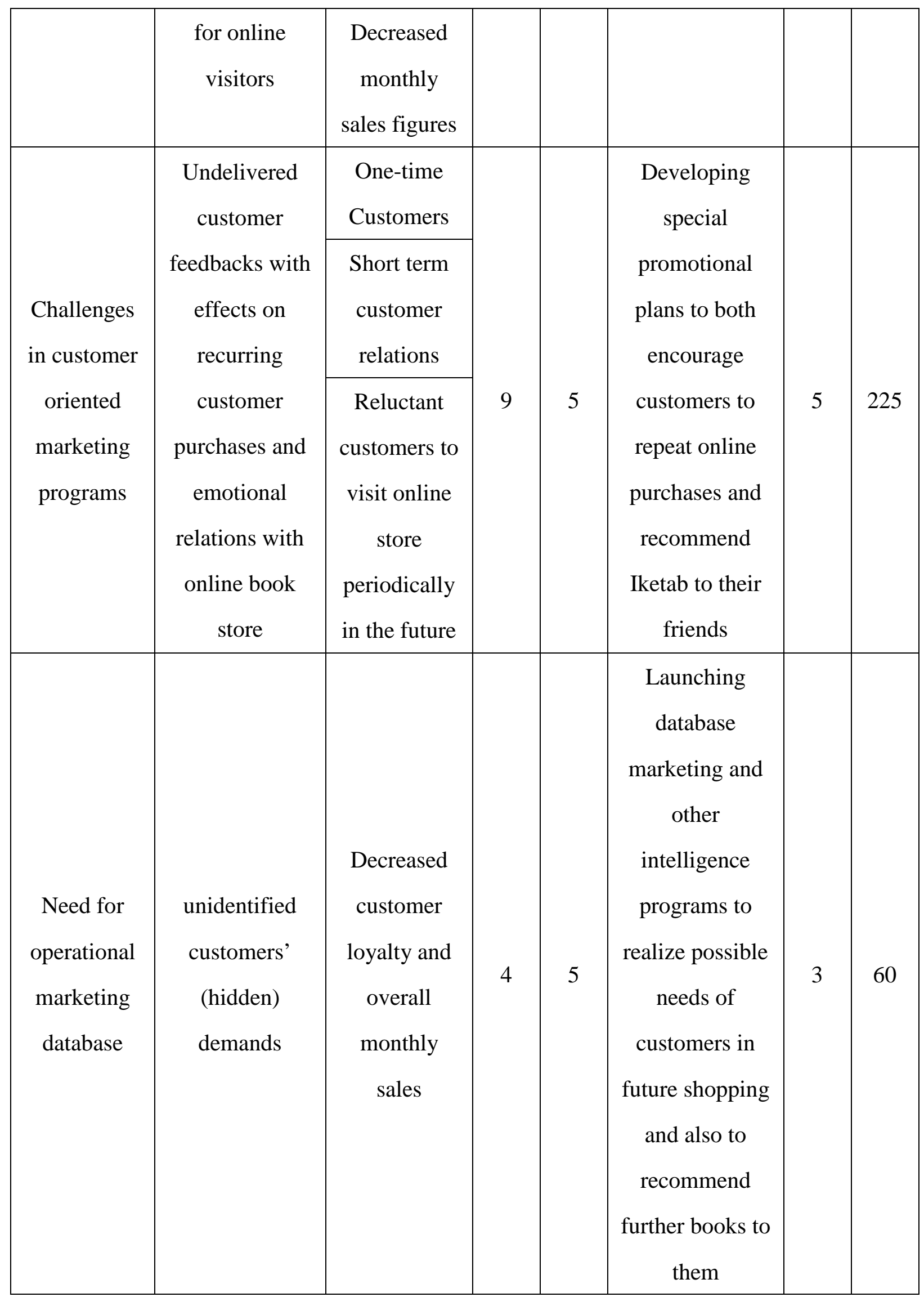


Cause and Effect Diagram: Once the failure mode with highest priority identified in FMEA, project team members use cause and effect diagram to investigate six factors (6P) that play role in occurrence of failure named: Challenges in customer oriented marketing programs: (1) Product/Service: Dynamic book market requires publishers and retailers to offer more variable book titles in different categories to the market. Iketab should revise or update its national and international publishers quarterly to offer newest book to customers. (2) Price: one advantage of shopping books from online book retailers is to benefit from their lower overall costs. Surveys show that specific customer segments like students are price sensitive enough to shop from web sites with distinct pricing policies. (3) Promotion: marketing experts believe that new promotion programs to loyal customers can result in higher brand equity. (4) People/personnel: e-marketing workshops make marketing team members familiar with the latest marketingtrends and techniques that lead to increased sales and satisfied customers in an online business environment. (5) Process: purchasing steps should bring a pleasant online shopping experience for customers. Quick Read is new program that enables online visitors to search and purchase a book without logging into their accounts. (6) Place: customers prefer to enjoy purchased services and products at their places. For customers in featured cities free delivery option is proposed to management. In other cities Iketab negotiates with main book stores to deliver purchased book online to addresses of customers for free. 


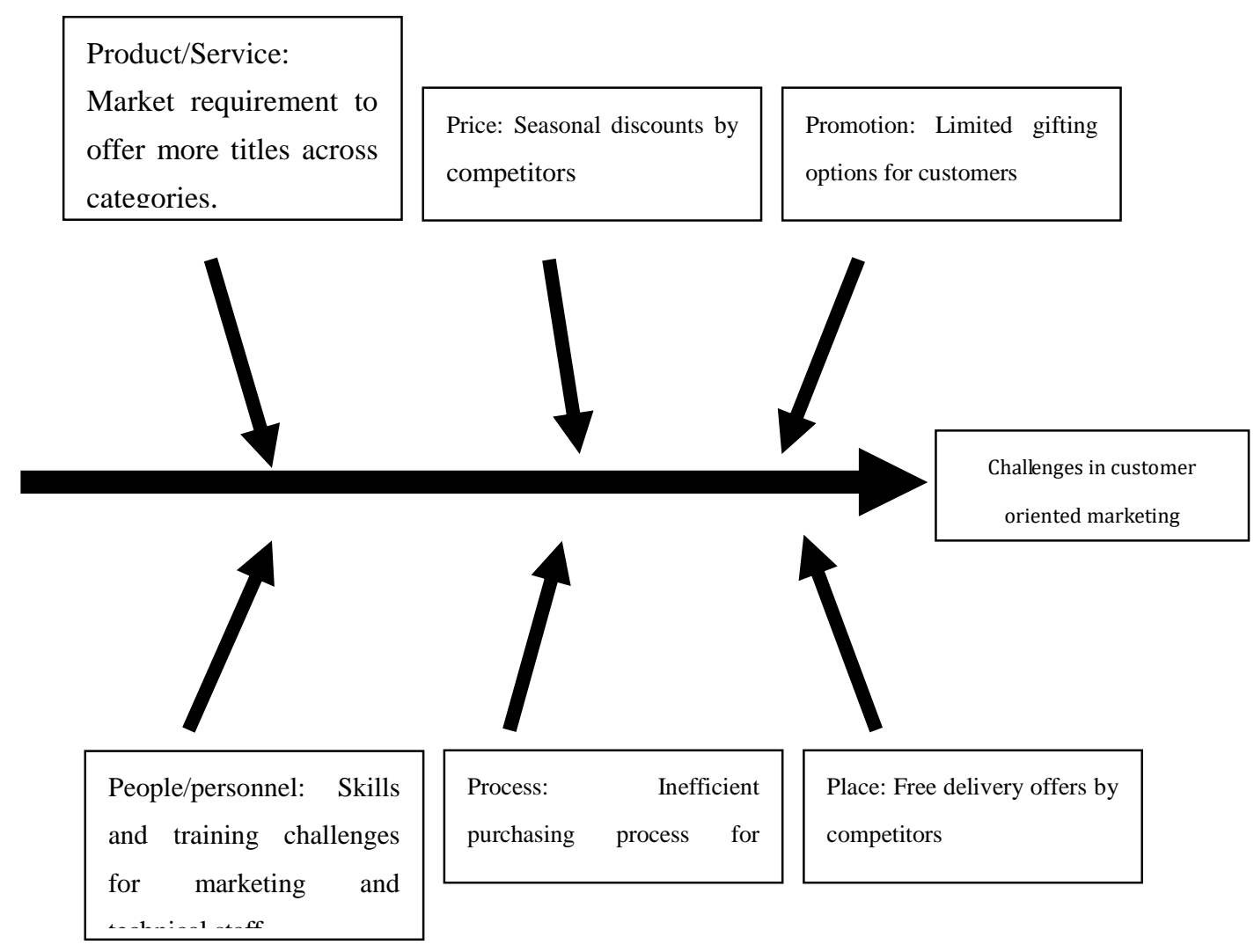

Fig.3. Cause and Effect Diagram

\section{Improve Phase}

In this phase, Six Sigma tools should be used to improve store's marketing process. The improvement actions covers main marketing failure modes with focus on one analyzed by cause and effect diagram (challenges in customer oriented marketing programs). As shown in table below, here we apply prioritization matrix to rank the narrowed solutions: (1) Leveraging-marketing techniques (social media marketing). (2) Revising purchasing steps. (3) Selling selected eBooks online. (4) Planning appropriate cultural events and commitment to social responsibilities. (5) Targeting schools' market. (6) Introduce a quality service into the marketplace. (7) Monitoring trends and competitors. (8) Build a consistent brand image. (9) Consistency of brand messaging. (10) Capture customer feedback.

These solutions must be considered regarding to some weighted criterions set by 20 store's administration and marketing team members and business advisors who were asked to weight each criterion from 0 to 10 : Increase marketing efficiency (0.11), Differentiating 
store'sservices in the market (0.27), Increase number of customers (0.23), Increasemonthly sales (0.20), Increase advertisements efficiency and customers' loyalty (0.09), Brand enrichment (0.10).

Table 8. Prioritization Matrix

\begin{tabular}{|c|c|c|c|c|c|c|c|c|c|}
\hline \multirow{2}{*}{\multicolumn{2}{|c|}{$\begin{array}{c}\text { Prioritization } \\
\text { Matrix }\end{array}$}} & \multicolumn{8}{|c|}{ Criteria } \\
\hline & & \multirow{2}{*}{$\frac{1}{0.66}$} & \multirow{2}{*}{$\frac{2}{2.43}$} & \multirow{2}{*}{$\frac{3}{1.61}$} & \multirow{2}{*}{$\begin{array}{c}4 \\
1.4\end{array}$} & \multirow{2}{*}{$\frac{5}{0.36}$} & \multirow{2}{*}{$\begin{array}{c}6 \\
0.7\end{array}$} & \multirow{2}{*}{$\frac{\text { Total }}{7.16}$} & \multirow{2}{*}{$\frac{\text { Rank }}{1}$} \\
\hline \multirow{10}{*}{ Solution } & 1 & & & & & & & & \\
\hline & 2 & 0.22 & 0.54 & 1.84 & 1.4 & 0.18 & 0.2 & 4.38 & 7 \\
\hline & 3 & 0.11 & 2.16 & 0.46 & 0.2 & 0.09 & 0.2 & 3.22 & 10 \\
\hline & 4 & 0.55 & 1.62 & 1.15 & 0.4 & 0.27 & 0.7 & 4.69 & 6 \\
\hline & 5 & 0.22 & 1.89 & 1.15 & 0.6 & 0.27 & 0.2 & 4.33 & 9 \\
\hline & 6 & 0.44 & 1.62 & 1.15 & 0.4 & 0.36 & 0.8 & 4.77 & 4 \\
\hline & 7 & 0.88 & 0.81 & 1.15 & 1.2 & 0.27 & 0.4 & 4.71 & 5 \\
\hline & 8 & 0.88 & 1.89 & 0.92 & 0.6 & 0.45 & 0.5 & 5.24 & 3 \\
\hline & 9 & 0.77 & 1.62 & 0.23 & 0.6 & 0.45 & 0.7 & 4.37 & 8 \\
\hline & 10 & 0.99 & 1.35 & 1.84 & 1 & 0.36 & 0.4 & 5.94 & 2 \\
\hline
\end{tabular}

In the next step, by using prioritization matrix, improvement actions are prioritized based on weighted criteria above, as shown in table below. In this regard, average of total scores (on how a specific solution leads to a certain criteria) is multiplied by weight of each criterion.

Prioritization matrix states that by development of new communication technologies, applying e-marketing techniques, such as advertisement and monitoring customers' attitudes in social media and networks is primary action to be taken by store to increase market share and benefit from more satisfied customers. Capturing customers' feedback is the second essential program that must be noted in each marketing programs. Users' perception on the efficiency of marketing performance is a unique source of data that marketing team members 
can use to analyze their current performance and make required changes to offer more desired services to all groups of customers.

\section{Control Phase}

Once online brand equity is improved by selected actions mentioned above, it is requested by managers to keep the improved process in a good shape.

In the last phase of DMAIC cycle, efforts are made to control the improved process andensure management about achievement of specified goals by using group of control tools for this phase. In this research, we applied revised FMEA based on solutions achieved in former phase.

The Revised FMEA is different from FMEA in three aspects. First it recommends specific control actions for each failure mode to ensure that the online business will benefit from enhanced brand equity will continue. Secondly, each series of actions for failure modes should be carried out on within a clear time limit. Timing is always a crucial element in projects. Finally project members report what certain control action they did in this phase. Last column of table also demonstrates that RPN of failure mode "Challenges in customer oriented marketing programs" has decreased after improvement actions to enhance online brand equity. 
Table 9. Revised FMEA

\begin{tabular}{|c|c|c|c|c|c|c|c|c|}
\hline $\begin{array}{l}\text { Failure } \\
\text { mode }\end{array}$ & $\begin{array}{l}\text { Recommended } \\
\text { actions }\end{array}$ & $\begin{array}{c}\text { Target } \\
\text { completion } \\
\text { date }\end{array}$ & $\sum_{2}^{2}$ & 赵 & & Actions taken & 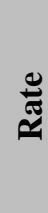 & $\underset{\mathbf{Z}}{\mathbf{Z}}$ \\
\hline \multirow{7}{*}{$\begin{array}{l}\text { Lack of } \\
\text { outstanding } \\
\text { competitive } \\
\text { advantage } \\
\text { over rivals }\end{array}$} & $\begin{array}{l}\text { Monitoring trends } \\
\text { and competitors. }\end{array}$ & \multirow{7}{*}{$2015 / 06 / 20$} & \multirow{7}{*}{5} & \multirow{7}{*}{\multicolumn{2}{|c|}{7}} & $\begin{array}{l}\text { Product life cycle planning for } \\
\text { each group of products }\end{array}$ & \multirow{7}{*}{3} & \multirow{7}{*}{105} \\
\hline & Introduce a quality & & & & & Market needs analysis & & \\
\hline & service into the & & & & & Introduction of exact service & & \\
\hline & marketplace & & & & & standards & & \\
\hline & Selling selected & & & & & Negotiation with publishers to & & \\
\hline & eBooks online & & & & & have e-format of selected books & & \\
\hline & $\begin{array}{l}\text { Targeting schools' } \\
\text { market }\end{array}$ & & & & & $\begin{array}{l}\text { Negotiation with selected } \\
\text { schools' managers to. }\end{array}$ & & \\
\hline \multirow{3}{*}{$\begin{array}{l}\text { Lacking } \\
\text { after-sales } \\
\text { customer } \\
\text { relations }\end{array}$} & $\begin{array}{l}\text { Capture customer } \\
\text { feedback }\end{array}$ & \multirow{3}{*}{$2015 / 07 / 10$} & \multirow{3}{*}{6} & \multirow{3}{*}{\multicolumn{2}{|c|}{3}} & $\begin{array}{l}\text { Adding required voting step to } \\
\text { the purchase process }\end{array}$ & \multirow{3}{*}{5} & \multirow{3}{*}{90} \\
\hline & $\begin{array}{l}\text { Leveraging } \\
\text { e-marketing } \\
\text { techniques }\end{array}$ & & & & & $\begin{array}{l}\text { Launching groups, campaigns } \\
\text { and channels in social media }\end{array}$ & & \\
\hline & $\begin{array}{l}\text { Revising } \\
\text { purchasing steps }\end{array}$ & & & & & $\begin{array}{l}\text { Defining Quick purchase method } \\
\text { for first time customers }\end{array}$ & & \\
\hline \multirow{4}{*}{$\begin{array}{c}\text { Challenges in } \\
\text { customer }\end{array}$} & $\begin{array}{l}\text { Build a consistent } \\
\text { brand image. }\end{array}$ & \multirow{4}{*}{$2015 / 02 / 05$} & \multirow{4}{*}{6} & \multirow{4}{*}{\multicolumn{2}{|c|}{4}} & $\begin{array}{l}\text { Planning quarterly marketing } \\
\text { research programs }\end{array}$ & \multirow{4}{*}{6} & \multirow{4}{*}{144} \\
\hline & $\begin{array}{l}\text { Consistency of } \\
\text { brand messaging }\end{array}$ & & & & & $\begin{array}{l}\text { Planning and focus to be the most } \\
\text { updated online book store in } \\
\text { Persian language }\end{array}$ & & \\
\hline & $\begin{array}{l}\text { Capture customer } \\
\text { feedback }\end{array}$ & & & & & $\begin{array}{l}\text { Categorizing customers to the } \\
\text { Gold, Silver or Bronze customers }\end{array}$ & & \\
\hline & $\begin{array}{l}\text { Commitment to } \\
\qquad \text { social } \\
\text { responsibilities }\end{array}$ & & & & & $\begin{array}{l}\text { Free delivery during highly } \\
\text { polluted days in large cities }\end{array}$ & & \\
\hline Lack of & $\begin{array}{l}\text { Capture customer } \\
\text { feedback }\end{array}$ & \multirow[b]{2}{*}{$2015 / 08 / 01$} & \multirow[b]{2}{*}{4} & \multirow{2}{*}{\multicolumn{2}{|c|}{2}} & $\begin{array}{l}\text { Adding required voting step to } \\
\text { the purchase process }\end{array}$ & \multirow[b]{2}{*}{4} & \multirow[b]{2}{*}{32} \\
\hline marketing & $\begin{array}{l}\text { Monitoring trends } \\
\text { and competitors. }\end{array}$ & & & & & $\begin{array}{c}\text { Planning weekly market research } \\
\text { committee }\end{array}$ & & \\
\hline
\end{tabular}




\section{CONCLUSION}

This paper studied the way an online book retailer applied Six Sigma to analyze and enhance its online brand equity. Based on Rios online brand equity model, online users were questioned how they feel towards store's brand's awareness, association value, association trust and loyalty. Under a three-sigma performance level we found that most defects are raised in marketing planning and programs. In particular, the results indicate that: (1) this novel research extends the application of quality initiatives in the field of marketing. While online businesses managers seek to increase their brand equity, we argued how available corporate branding data can be explored to increase quality of marketing indicators. (2) One important fact in enhancing online brand equity is the role of e-marketing and social media marketing for online businesses today. More businesses use social marketing to help to identify their most influential consumers, drive participants in product/ service development and improve brand engagement. This means that by development of new marketing tools, customers rely more on their points of view when making purchasing decisions, rather than advertisements by companies. (3) Similar online book selling businesses available in Iran's book industry requires all market players to differ their customer support service. In connection with findings of improve phase (second improvement action), the online store is advised to add online opinion polls to align its marketing and sales programs with changing customers' needs and preferences.

\section{REFERENCES}

[1] Aaker, D. (1991). Managing Brand Equity: Capitalizing on the Value of a Brand Name. Free Press.

[2] Aaker, D., \& Joachimsthaler, E. (2000). Brand Leadership. London: The Free Press.

[3] Abels E.G, White M. D, \& Hahn K. A user-based design process for websites. OCL Systems and services, 1999, 15, 35-44.

[4] Aboelmaged, M. Six Sigma quality: a structured review and implications for future research. International Journal of Quality \& Reliability Management, 27(3). Emerald Group Publishing Limited, 2010. 
[5] Aghaie, M, Vahedi E, Asadollahi A, \& Safari-Kahreh M. An empirical investigating to Effects of services marketing mix on Brand Dimensions in Order to enhance brand Equity in the Tehran's Chain Stores. Research Journal of Recent Sciences, 2014, 3(2), 43-60.

[6] Ambler, T. Need-to-know-marketing. London: Century Business, 1992.

Antony J. Six Sigma for service processes. Business Process Management Journal, 2006, 12(2), 234-248.

[7] ASSAEL H. Consumer behavior and marketing action, Boston MA, PWS-Kent, 1992

[8] Bowker, D. The public relation perspective on branding. The Economist in association with Profile Books LTD, 2003

[9] Brown, G. People, brands and advertising. New York: Millward Brown International, 1992

[10] Brymer, C. What Makes Brands GREAT? Journal of Marketing, 20-22, 2004.

[11] Buil I, Chernatony, L, \& Martinez E. A cross-national validation of the consumer based brand equity scale. Journal of Product \& Brand Management, 2008, 17: 384-392.

[12] Carpenter, P. eBrands: Building an Internet Business at Breakneck Speed. Boston, MA: Harvard Business School Press, 2000.

[13] Chakrabarty, A., \& Chuan, T. The current state of six sigma application in services. Managing Service Quality, 2007, 17(2). Emerald Group Publishing Limited.

[14] Chen, S. (2001). Assessing the impact of the Internet on brands. Journal of Brand Management, 8, 288-302.

[15], Cheng F. F, Wu C. S, \& Yen H. Proceedings from 15th International Business Research Conference: The influence of online communication, word of mouth and virtual community on online brand equity. Sydney, Australia, 2011, November 21-23.

[16] Christodoulides, G., Chernatoni, L., Furrer, O., Shiu, E., \& Abimbola, T. Conceptualising and measuring the equity of online brands. Journal of Marketing Management, 2006, 22: 799-825.

[17] Davis, R., Buchanan, M., \& Brodie, R. J. Retail service branding in electronic-commerce environments. Journal of Service Research, 2000, 3: 178-186. 
[18] Dayal, S., Landesberg, H., \& Zeisser, M. (). Building digital brands. The McKinsey Quarterly, 2000, 2: 42-51.

[19] Delgado, C., Ferreira, M., \& Castelo Branco, M. The implementation of lean Six Sigma in financial services organizations. Journal of Manufacturing Technology Management, 2010, 21(4), 512-523.

[20] Edrem T., Swait J. and Valenzuela A. Brands as signals: A cross-country validation study, Journal of Marketing, 2006, 70(1), 34-49

[21] Farquhar,P.H. and Herr,P.M,The Dual Structure of Brand Association, Brand Equity and Advertising , 1993: 263-277.

[22] Farquhar, P, Managing Brand Equity, Marketing Research, vol. 1,September, 1989: 24-33.

[23] Keller, K. L. Conceptualizing, Measuring, and Managing Customer-Based Brand Equity, Journal of Marketing, 1993, 57: 1-22.

[24] Farris, P. W., Bendle, N. T., Pfeifer, P. E., \& Reibstein, D. J. Marketing Metrics: +50 Metrics Every Executive should Master.Wharton, NJ: Wharton School, 2006.

[25] Gorriz, C. Electric commerce and trust on the Internet. IN SRIC-BI (Ed.) SRI Consulting Business Intelligence. Menlo Park, California, SRIC-BI, 2003.

[26] Jenicke, L. O., Kumar, A., \& Holmes, M. C. A framework for applying Six Sigma improvement methodology in an academic environment. The TQM Journal, 2008, 20(5), 453-462.

[27] Jernelid, M., \& Roan, S. Six Sigma strategy applied to the pharmaceutical industry, how customers benefit (MBA thesis). School of Management, Blekinge Institute of Technology, Karlskrona. Retrieved from www.essays.se/essay/86f235395b, 2009.

[28] Johnson, T., \& Griffith, D. 5 steps online success. Marketing Management, 2002, 11: 35-39.

[29] Kamakura WA, \& Russell GJ Measuring Brand Value with Scanner Data. International Journal of Research in Marketing, 1993, 10: 9-22.

[30] Keller, K. L. Strategic Brand Management: Building, Measuring, and Managing Brand Equity (2nd Ed.). Upper Saddle River, NJ: Pearson Education, 2003. 
[31] Kim, J., Sharma, S., \& Setzekorn, K. A Framework for Building Brand Equity Online for Pure-Play B2C Retailers and Services. The international journal on Media Management, 2002, 4: 123-133.

[32] Kim, J., Reid, D. S., Plank, R. E. \& Dahlstrom, R, Examining the Role of Brand Equity in Business Markets: A Model, Research Propositions, and Managerial Implication, Journal of Business-to-Business Marketing, 1998,5(3): 65-89.

[33] Kapferer, J.N. The New Strategic Brand Management: Creating and Sustaining Brand Equity Long Term. London: Kogan Page, 2004.

[34] Kotler, P., Lee, N., Farris, P. W., Bendle, N. T., Pfeifer, P. E., Reibstein, D. J., . . Reece, M. Marketing Strategy from the Masters (Collection). FT Press, 2010.

[35] Kumi, S., \& Morrow, J. Improving self service the Six Sigma way at Newcastle University Library. Electronic Library and Information Systems, 2006, 40(2): 123-36.

[36] Lassar, W., Mittal, B., \& Sharma, A. Measuring customer-based brand equity. Journal of Consumer Marketing, 1995, 12: 11-19.

[37] Leone, R. P., Rao, V. R., Keller, K. L., Lui, A. M., Mcalister, L., \& Srivastava, R. Linking brand equity to customer equity. Journal of Service Research, 2006, 9: 125- 138.

[38] Manual, D. Six Sigma methodology: reducing defects in business processes. Filtration \& Separation, 2006, 43(1): 34-6.

[39] Martensen, A., Grønholdt, L., \& Trajcevski, S. (2004, May 20-23). Proceedings from the 8th International Conference on Corporate Reputation, Identity and Competitiveness, Fort Lauderdale, Florida: Building customer-brand relationships on the Internet: Development of an online brand equity model..

[40] Myers, C. Managing brand equity: a look at the impact of attributes. Journal of Product \& Brand Management2003, 12, 39- 51.

[41] Netemeyer, R. G, Krishnan B, Pullig C, Wang G, Yagci M, Dean D, Ricks J, \& Wirth F. Developing and validating measures and facets of customer based brand equity. Journal of Business Research, 2004, 57: 209-224. 
[42] Oliya, E., Owlia, M.S, Dehdashti, Z. \& Olfat, L. Improving marketing process using Six Sigma techniques (case of Saman Bank). International Journal of Lean Six Sigma, 2012, 3(1): 59-73.

[43] Page, C., \& Lepkowska-white, E. Web equity: a framework for building consumer value in online companies. Journal of Consumer Marketing, 2002, 19: 231- 248.

[44] Pestorius, M. Apply Six Sigma to sales and marketing. Quality Progress, 2007, 40(1): 19-24.

[45] Raisinghani, M. S., Ette, H., Pierce, R., Cannon, G., \& Daripaly, P. Six Sigma: concepts,tools and applications. Industrial Management \& Data Systems, 2005, 105(4): 491-505.

[46] Rath \& Strong. (2006). Rath \& Strong's Six Sigma Pocket Guide. Rath \& Strong publication

[47] Rios, R. E. (2007). Sources and antecedents of brand equity for online companies. Melbourn.

[48] Rios, R. E., \& Riquelme, H. E. Brand Equity for online companies. Marketing Intelligence \& Planning, 2008, 719-742.

[49] Rubinstein, H., \& Griffith, C. Branding matters more on the Internet. The Journal of Brand Management, 2001, 8: 394-404.

[50] Segismundo, A., \& Cauchick Miguel, P. A. Failure mode and effects analysis (FMEA) in the context of risk management in new product development.A case study in an automotive company. International Journal of Quality \& Reliability Management, 2008, 25(9): 899-912.

[51] Staudter, C., Mollenhauer, J. P., Meran, R., Roenpage, O, von Hugo, C., \& Hamalides, A. (2009). Design for Six Sigma +Lean Toolset. Berlin: Springer.

[52] Taylor, S., Hunter, G., \& Linderberg, D. Understanding customer-based brand equity in financial services. Journal of Services Marketing, 2007, 21: 241- 252.

[53] Urde, M. Brand orientation: A mindset for building brands into strategic resources. Journal of Marketing Management, 1999, 15: 117-133.

[54] Webster, F. Understanding the relationships among brands, consumers, and resellers. Journal of the Academy of Marketing Science, 2000, 28: 17-23. 
[55] Wood, L. Brands and brand equity: definition and management. Management Decision, 2000, 39: 662-669.

[56] Yoo, B. and Donthu, N. Developing and Validating a Multidimensional Consumer-Based Brand Equity Scale, Journal of Business Research, 2001, 52(1): 1-14.

[57] Zhang, L., \& Khan, A. R. Applying Six Sigma in Software Companies for Process Improvement (Master Thesis). School of Engineering, Blekinge Institute of Technology. Retrieved from http://www.essays.se/essay/5415e71a9c, 2008.

\section{How to cite this article:}

Hataminasab S H, Oliya E, Torabi Z, Roghani F S. Service quality \& marketing: a practical relation. J. Fundam. Appl. Sci., 2016, 8(2S), 1314-1343. 